\title{
Determination of Rocks Elastic constants from Compressional and Shear Waves Velocities for Western Niger Delta, Nigeria.
}

\author{
EMUJAKPORUE, G. O.; EKINE, A. S. \\ Department of Physics, University of Port Harcourt, Nigeria.E-mail: owin2009@yahoo.com
}

\begin{abstract}
The elastic properties of sedimentary rocks in the western Niger delta, Nigeria, have been computed for five oil exploratory wells. The elastic properties were obtained from the continuous borehole seismic (compressional and shear waves) velocities and density logs. The computed Lame's constants, $\mu$ and $\lambda$ range from $0.02 \times 10^{10}$ to $1.0 \times 10^{10} \mathrm{~Pa}$ and $0.26 \times 10^{10}$ to $1.3 \times 10^{10} \mathrm{~Pa}$ respectively. The computed values of the Young's modulus, $\mathrm{E}$, range between $0.56 \times 10^{10}$ and $2.53 \times 1010 \mathrm{~Pa}$. The values of the bulk modulus, $\mathrm{K}$, and compressibility, $\beta$, vary from $0.64 \times 10^{10}$ to $2.16 \times 10^{10} \mathrm{~Pa}$ and from $0.11 \times 10^{-11}$ to $9.4 \times 10^{-11} \mathrm{~Pa}^{-1}$ respectively. The values of the bulk modulus are the largest for all the wells. The calculated values of the Poisson's ratio, $\sigma$, are between 0.2 and 0.41 . The computed values of the elastic properties show that the rocks encountered in the wells are soft and poorly sorted. This is a confirmation of the fact that the wells encountered two major formations (Benin and Agbada Formations). The Benin Formation is made up of sands with high porosity while the Agbada Formation is made up of alternations of sands and shale lithologies. @ JASEM
\end{abstract}

Rock elastic properties are a source of valuable information for most projects in rock mechanics as the knowledge of deformational characteristics of rocks is essential in locating and extracting mineral resources, and in the design and construction of any structure on the rock (Farmer, 1983; Tiab and Donaldson, 1999). The seismic method utilizes the propagation of waves through the earth. Wave propagation depends upon the elastic properties of rocks (Sheriff, 1989). A stress applied to the surface of a body tends to change the size and shape of the body. The external stress gives rise to opposing forces within the body. The ability to resist deformation and the tendency of the body to restore itself to the original size and shape defines the elasticity of the particular material. A perfectly elastic body is one that recovers completely after being deformed. Many substances including rocks can be considered to be perfectly elastic without appreciable error provided the deformations are small as is the case in seismic surveys. The theory of elasticity relates the forces which are applied to the external surface of a body to the resulting changes in size and shape. The relations between the applied forces and the deformations are mostly conveniently expressed in terms of the concepts of stress and strain as stated in Hooke's law. The constant of proportionality is called an elastic constant or modulus (Telford et al., 1985; Sheriff and Geldart, 1995; Omodu and Ebeniro, 2005). Oil exploration activity in the Niger Delta sedimentary basin has resulted in the accumulation of many seismic and well log data. Shear and compressional waves velocities and density logs have been acquired in many wells from which the elastic properties of the Formations can be obtained. This work, therefore will attempt to compute the various elastic properties of rocks within the area of study using borehole seismic velocities and density logs obtained from five oil exploratory wells located within the western parts of the Niger delta.

\section{SUMMARY OF THE GEOLOGY OF THE NIGER DELTA}

The Niger Delta is the youngest sedimentary basin within the Benue Trough system. The Niger delta development began after the Eocene tectonic phase. Up to $12.0 \mathrm{~km}$ of deltaic and shallow marine sediments have been accumulated in the basin. The Niger and Benue Rivers are the main supplier of sediments. Three lithostratigraphic units are distinguished in the Tertiary Niger Delta. The basal Akata Formation which is predominantly marine prodelta shale is overlain by the paralic sand/shale sequence of the Agbada Formation. The topmost section is the continental upper deltaic plain sands the Benin Formation. Virtually all the hydrocarbon accumulations in the Niger Delta occur in the sands and sandstones of Agbada Formation where they are trapped by rollover anticlines related to growth fault development (Ekweozor and Daukoru, 1994; Michele et al., 1999; Uko, 1996).

\section{MATERIALS AND METHODS}

The basic data used for this work comprise a set of shear wave velocity, compressional velocity and density logs obtained from exploratory oil wells in the Niger Delta sedimentary basin. The geophysical $\operatorname{logs}$ available for the wells vary in completeness from one well to the other. As a result, the data set could not be limited to a particular depth range for all the wells. The data were obtained from Shell Petroleum Development Company (Ogagarue, 2007). The propagation speed of seismic waves through the earth depends on the elastic properties and density of the material. The elastic properties of any medium

* Corresponding author: Emujakporue, G. O. 
can be determined from velocity and density $(\mathrm{V}, \rho)$ measurements (Sheriff and Geldart, 1995; Sheriff, 1989; Parasnis, 1986; Wang, 2001; Ramana and Rao, 1987). The velocities of the longitudinal and transverse waves, designated $\mathrm{V}_{\mathrm{p}}$ and $\mathrm{V}_{\mathrm{s}}$ respectively, are expressed in terms of Lame's constants, $\mu$ and $\lambda$ as:

and

$$
\mathrm{V}_{\mathrm{p}}=((\lambda+2 \mu) / \rho)^{1 / 2}
$$

$$
\mathrm{V}_{\mathrm{s}}=(\mu / \rho)^{1 / 2}
$$

The other elastic constants of the rock are related to the Lame's constant as follow:

and

$$
\begin{aligned}
& \mathrm{E}=\mu(3 \lambda+2 \mu) \div(\lambda+\mu) \\
& \sigma=\lambda \div 2(\lambda+\mu)
\end{aligned}
$$

$$
\mathrm{K}=1 / 3(3 \lambda+2 \mu) \quad 5
$$

The inverse of $\mathrm{K}$ is given as:

$$
\beta=\mathrm{K}^{-1}
$$

where $\mathrm{V}_{\mathrm{p}}=$ compressional velocity; $\mathrm{V}_{\mathrm{s}}=$ shear velocity; $\lambda$ and $\mu=$ Lame's constants

$\mathrm{E}=$ Young's modulus; $\sigma=$ Poisson's ratio; $\mathrm{K}=$ Bulk modulus; $\beta=$ Compressibility.

Most of the preceding theory assumes an isotropic medium. In fact rocks are usually in layers with different elastic properties, these properties often varying with direction. Nevertheless, discussing wave propagation, we generally ignore such differences and treat sedimentary rocks as isotropic media; when one does so, the results are useful and to do otherwise leads to extremely complex and cumbersome mathematical equations.

\section{RESULTS AND DISCUSSION}

The computed elastic constants of the sedimentary rocks in the western Niger delta are given in Table 1. The major lithologies encountered in the wells are shales and sands. The depths investigated vary from one well to the other. The calculated values of the Lames constants $\mu$ and $\lambda$ vary from 0.26 to $1.7 \times 10^{10}$ and from 0.64 to $2.16 \times 10^{10} \mathrm{~Pa}$ respectively. The Young's modulus, E, which is a measure of the property of the rock to resist deformation ranges from 0.56 to $2.53 \times 10^{10} \mathrm{~Pa}$. The value for the Young's modulus is higher for the sand lithology than for the shales. The computed Poisson's ratios, $\sigma$, for the various wells vary between 0.2 and 0.41 for both sand and shale lithologies in the wells. The result shows that rocks in the area are soft, porous and are poorly sorted. Another important elastic constant, the bulk modulus, $\mathrm{K}$, which is the ratio of change in hydrostatic pressure to the corresponding volumetric strain has computed values varying between 0.64 and

\begin{tabular}{|c|c|c|c|c|c|c|c|c|c|c|c|}
\hline Well & $\begin{array}{l}\text { Depth } \\
\text { (m) }\end{array}$ & $\begin{array}{l}\mathrm{V}_{\mathrm{p}} \\
(\mathrm{m} / \mathrm{s})\end{array}$ & $\begin{array}{l}V_{\mathrm{s}} \\
(\mathrm{m} / \mathrm{s})\end{array}$ & $\begin{array}{l}\text { Density } \\
\left(\mathrm{Kg} / \mathrm{m}^{3}\right)\end{array}$ & $\begin{array}{l}\mu \\
10^{10} \mathrm{~Pa}\end{array}$ & $\begin{array}{l}\lambda \\
10{ }^{10} \mathrm{~Pa}\end{array}$ & $\begin{array}{l}\mathrm{K} \\
10^{10} \mathrm{~Pa}\end{array}$ & $\sigma$ & $\begin{array}{l}\mathrm{E} \\
10^{10} \mathrm{~Pa}\end{array}$ & $\begin{array}{cc}\beta & 10^{-} \\
{ }^{11} \mathrm{~Pa}^{-1}\end{array}$ & Lithology \\
\hline 1 & $\begin{array}{l}2684- \\
2690\end{array}$ & $\begin{array}{l}2790- \\
3118\end{array}$ & $\begin{array}{l}1233- \\
1515\end{array}$ & $\begin{array}{l}2110- \\
2200\end{array}$ & $\begin{array}{l}0.331- \\
0.51\end{array}$ & $\begin{array}{l}1.03- \\
1.14\end{array}$ & $\begin{array}{l}1.26- \\
1.48\end{array}$ & $\begin{array}{l}0.34- \\
0.38\end{array}$ & $\begin{array}{l}0.91- \\
1.37\end{array}$ & $\begin{array}{l}6.76- \\
7.97\end{array}$ & Sand \\
\hline$"$ & $\begin{array}{l}2686- \\
2794\end{array}$ & $\begin{array}{l}2547- \\
3094\end{array}$ & $\begin{array}{l}829- \\
1618\end{array}$ & $\begin{array}{l}2160- \\
2430\end{array}$ & $\begin{array}{l}0.28- \\
0.60\end{array}$ & $\begin{array}{l}0.9- \\
1.2\end{array}$ & $\begin{array}{l}1.1- \\
2.16\end{array}$ & $\begin{array}{l}0.33- \\
0.40\end{array}$ & $0.6-1.6$ & $\begin{array}{l}4.64- \\
8.74\end{array}$ & Shale \\
\hline 2 & $\begin{array}{l}3002- \\
3067\end{array}$ & $\begin{array}{l}3065- \\
3541\end{array}$ & $\begin{array}{l}1734- \\
1915\end{array}$ & $\begin{array}{l}2190- \\
2520\end{array}$ & $\begin{array}{l}0.67- \\
1.10\end{array}$ & $\begin{array}{l}0.4- \\
1.3\end{array}$ & $\begin{array}{l}1.0- \\
1.8\end{array}$ & $\begin{array}{l}0.2- \\
0.32\end{array}$ & $\begin{array}{l}1.73- \\
2.53\end{array}$ & $\begin{array}{l}5.5- \\
9.4\end{array}$ & Shale \\
\hline$"$ & $\begin{array}{l}3165- \\
3180\end{array}$ & $\begin{array}{l}3422- \\
3626\end{array}$ & $\begin{array}{l}1894- \\
2046\end{array}$ & $\begin{array}{l}2170- \\
2250\end{array}$ & $\begin{array}{l}0.79- \\
0.94\end{array}$ & $\begin{array}{l}0.96- \\
1.07\end{array}$ & $\begin{array}{l}1.51- \\
1.7\end{array}$ & $\begin{array}{l}0.27- \\
0.29\end{array}$ & $\begin{array}{l}2.03- \\
2.4\end{array}$ & $\begin{array}{l}5.87- \\
6.87\end{array}$ & Sand \\
\hline 3 & $\begin{array}{l}2510- \\
2564\end{array}$ & $\begin{array}{l}2856- \\
3160\end{array}$ & $\begin{array}{l}1373- \\
1559\end{array}$ & $\begin{array}{l}2030- \\
2230\end{array}$ & $\begin{array}{l}0.42- \\
0.50\end{array}$ & $\begin{array}{l}0.8- \\
1.28\end{array}$ & $\begin{array}{l}1.23- \\
1.6\end{array}$ & $\begin{array}{l}0.31- \\
0.37\end{array}$ & $\begin{array}{l}1.05- \\
1.47\end{array}$ & $\begin{array}{l}6.11- \\
9.21\end{array}$ & Shale \\
\hline$"$ & $\begin{array}{l}2890- \\
2921\end{array}$ & $\begin{array}{l}2910- \\
3169\end{array}$ & $\begin{array}{l}1454- \\
1986\end{array}$ & $\begin{array}{l}2170- \\
2250\end{array}$ & $\begin{array}{l}0.47- \\
0.98\end{array}$ & $\begin{array}{l}0.78- \\
1.27\end{array}$ & $\begin{array}{l}0.8- \\
1.62\end{array}$ & $\begin{array}{l}0.12- \\
0.36\end{array}$ & $\begin{array}{l}1.28- \\
1.91\end{array}$ & $\begin{array}{l}6.1- \\
8.46\end{array}$ & Sand \\
\hline 4 & $\begin{array}{l}2440- \\
2742\end{array}$ & $\begin{array}{l}2803- \\
3446\end{array}$ & $\begin{array}{l}984- \\
1634\end{array}$ & $\begin{array}{l}2160- \\
2570\end{array}$ & $\begin{array}{l}0.23- \\
0.686\end{array}$ & $\begin{array}{l}0.78- \\
1.7\end{array}$ & $\begin{array}{l}1.12- \\
1.74\end{array}$ & $\begin{array}{l}0.28 \\
0.34\end{array}$ & $\begin{array}{l}0.68- \\
1.68\end{array}$ & $\begin{array}{l}5.76- \\
8.48\end{array}$ & Shale \\
\hline$"$ & $\begin{array}{l}2745- \\
2928\end{array}$ & $\begin{array}{l}930- \\
1919\end{array}$ & $\begin{array}{l}930- \\
1919\end{array}$ & $\begin{array}{l}2080- \\
2320\end{array}$ & $\begin{array}{l}0.02- \\
0.07\end{array}$ & $\begin{array}{l}0.26- \\
1.7\end{array}$ & $\begin{array}{l}0.64- \\
1.83\end{array}$ & $\begin{array}{l}0.142- \\
0.41\end{array}$ & $\begin{array}{l}0.56- \\
2.03\end{array}$ & $\begin{array}{l}5.46- \\
15.6\end{array}$ & Sand \\
\hline 5 & $\begin{array}{l}2630- \\
2698\end{array}$ & $\begin{array}{l}2804- \\
3087 \\
\end{array}$ & $\begin{array}{l}1290- \\
1561\end{array}$ & $\begin{array}{l}2090- \\
2420 \\
\end{array}$ & $\begin{array}{l}0.386- \\
0.59 \\
\end{array}$ & $\begin{array}{l}0.71- \\
1.18 \\
\end{array}$ & $\begin{array}{l}0.98- \\
1.53 \\
\end{array}$ & $\begin{array}{l}0.26- \\
0.36\end{array}$ & $\begin{array}{l}0.99- \\
1.55 \\
\end{array}$ & $\begin{array}{l}6.52- \\
10.2 \\
\end{array}$ & Shale \\
\hline$"$ & $\begin{array}{l}2756- \\
2835\end{array}$ & $\begin{array}{l}2749- \\
3066\end{array}$ & $\begin{array}{l}1326- \\
1630\end{array}$ & $\begin{array}{l}2070- \\
2210\end{array}$ & $\begin{array}{l}0.35- \\
0.578\end{array}$ & $\begin{array}{l}0.606- \\
1.12\end{array}$ & $\begin{array}{l}0.94- \\
1.37\end{array}$ & $\begin{array}{l}0.27- \\
0.36\end{array}$ & $\begin{array}{l}0.98- \\
1.50\end{array}$ & $\begin{array}{l}0.11- \\
8.50\end{array}$ & Sand \\
\hline
\end{tabular}
$2.16 \times 10^{10} \mathrm{~Pa}$ for both shale and sand lithologies encountered in the wells. The computed values of the compressibility, $\beta$, similarly vary from 5.0 to $16 \times 10^{-}$ ${ }^{11} \mathrm{~Pa}^{-1}$ for all the wells.

Table 1: Summary of the Elastic Properties for wells in the Western Niger Delta.

* Corresponding author: Emujakporue, G. O. 
Conclusion: The knowledge of the seismic velocities of a rock can provide valuable information about the bulk physical properties of the rock including how the rock will deform under a given stress. This type of information can be invaluable during the design and construction phases of projects. The state of stress within a given volume of rock is often of great concern during the construction of large structures. The computed values of the elastic constants agree with the valued obtained in other sedimentary areas. The values show that the rocks within the study areas are soft, porous and are poorly sorted. This is in conformity with the fact that the major formations encountered in the wells are the Benin and Agbada Formations. The Benin Formation is made up of sand layers while the Agbada Formation is made up of alternations of sands and shales. The elastic constants can also be obtained from laboratory measurements, which allow for direct measurements of strength parameters and static behaviour with recovered core samples from discrete depths. Lack of core samples has limited us from using this method and subsequently comparing the two values.

\section{REFERENCES}

Ekweozor, C M; Daukoru, E M (1994). Northern delta depobelt portion of the Akata- Agbada. (1) Petroleum system, Niger Delta, Nigeria, In, Magom, L.B., and Dow, W.G., eds. The petroleum system- from source to Trap. A. A. P. G. Memoir 60: Tulsa, $599-614$.

Farmer, I (1983). Engineering behaviour of rocks, $2^{\text {nd }}$ edition. Chapman and Hall Ltd., London, England.

Fowler, C. M. R (1999). The solid earth: An Introduction to Global Geophysics. $1^{\text {st }}$ edition. Cambridge University Press, UK.

Michele, L W T; Ronald, R C; Michael, E B (1999). The Niger delta petroleum system: Niger delta province, Nigeria, Cameroon, and Equatorial Guinea, Africa. Open-file report 99-50-H.
Ogagarue, D O (2007). Seismic anisotropy in western Niger Delta sedimentary basin. Unpublished $\mathrm{Ph}$. D. Thesis, University of PortHarcourt, PortHarcourt.

Omodu, L M; Ebeniro, J O (2005). Cross-plotting of rock properties for fluid discrimination using well data in offshore Niger delta. Nig. Journ. Physics, 17: 16-20.

Parasnis, D S (1986). Principles of Applied Geophysics. $4^{\text {th }}$ edition, Chapman and Hall, London

Ramana, Y V; Rao, M S (1987). Compressional velocities in ultramafic rocks of India at pressures to five kilobars. Geophysical Journ. Royal Astro. Soc., 37: 207 - 212.

Sheriff, R E (1989). Geophysical methods $1^{\text {st }}$ edition. Prentice Hall, New Jersey.

Sheriff, R E; Geldart, L P (1995). Exploration seismology. $2^{\text {nd }}$ edition, Cambridge University Press, New York

Telford, W M; Geldart, I. P; Sheriff, R E; Keys, D. A (1985). Applied Geophysics; Cambridge University Press, Cambridge, London.

Tiab, D; Donaldson, E C(1999). Petrophysics: Theory and practice of measuring reservoir rock and fluid transport properties. $1^{\text {st }}$ edition. Gulf Publishing Company, Houston.

Uko, E D (1996). Thermal modeling of the Northern Niger delta. Unpublished $\mathrm{Ph}$.D. Thesis, Rivers State University of Science and Technology, Port Harcourt.

Wang, Z (2001). Fundamentals of seismic rock properties. Geophysics, 66: $398-412$.

* Corresponding author: Emujakporue, G. O. 